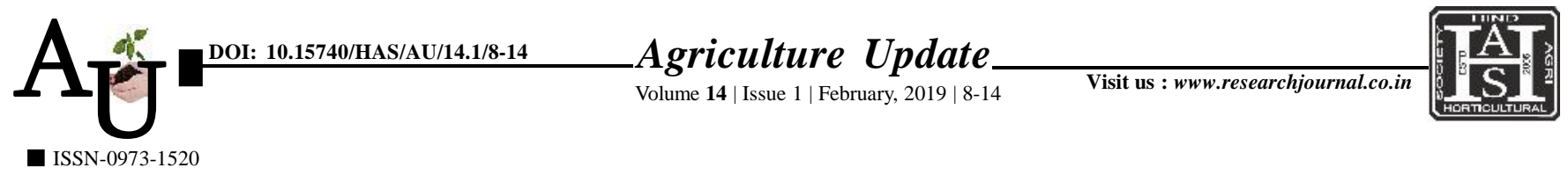

\title{
Research Article: A study on level of knowledge on recommended package of practices of rice growers
}

\author{
Maddina Sreekanth, A.H. Hakeem, Qadri Javid Ahmad Peer and Farhana
}

Article Chronicle: Received : 24.05.2018;

Revised : 26.12.2018; Accepted : 02.01.2019

KeY Words : Knowledge, Package of practices, Rice, Rice growers

Author for correspondence : Qadri Javid Ahmad Peer Division of Agriculture Extension and Communication, Faculty of Agriculture, Sher-eKashmir University of Agricultural Sciences and Technology of Kashmir, Kashmir (J\&K) India Email:qadrijavid2008@ gmail.com

See end of the article for authors' affiliations
SUMMARY : The study was conducted in 3 tehsils of Baramulla district namely Sopore, Bomai and Pattan from which 4 villages from each tehsil were selected randomly that makes a total of 12 villages and 10 rice growers from each village those who cultivate rice above half an acre were purposively selected that makes a sample size of 120 rice growers for the study. It was found that majority of the respondents were middle aged and literates with medium family size, possessing land holding of 4-10 kanals. Majority of the respondents dependent on agriculture for their livelihood with medium farming experience, annual income, mass media exposure and scientific orientation whereas majority of the respondents had low social participation and extension contacts. Independent variables education, occupation, social participation, annual income, mass media exposure, extension contacts and scientific orientation had positive and significant relation with the knowledge level of respondents. Majority of the respondents had medium knowledge regarding the package of practices for rice cultivation recommended by SKUAST-Kashmir.

How to cite this article : Sreekanth, Maddina, Hakeem, A.H., Peer, Qadri Javid Ahmad and Farhana (2019). A study on level of knowledge on recommended package of practices of rice growers. Agric. Update, 14(1): 8-14; DOI : 10.15740/HAS/AU/14.1/8-14. Copyright@ 2019: Hind Agri-Horticultural Society. 